\title{
Removal of copper, nickel and lead from wastewater using a modified cellulose material: a comparison
}

\author{
D. W. O'Connell ${ }^{1,3}$, C. Birkinshaw ${ }^{2,3} \&$ T. F. O’Dwyer ${ }^{1,3}$ \\ ${ }^{1}$ Chemical \& Environmental Sciences Department, \\ University of Limerick, Ireland \\ ${ }^{2}$ Materials Science \& Technology Department, \\ University of Limerick, Ireland \\ ${ }^{3}$ Materials \& Surface Science Institute, University of Limerick, Ireland
}

\begin{abstract}
Heavy metal waste streams from a variety of industrial sources pose a significant environmental threat to receiving waters. Significant research work has focused on the use of adsorbents and adsorption in the treatment and recovery of these metals from waste streams. This paper focuses specifically on the design of a novel adsorbent based on the naturally occurring material, cellulose and application of this novel material to the removal of selected heavy metals from waste streams. Cellulose material has limited heavy metal adsorbing capability. To enhance its sorption capacity, a sorbent material was prepared by firstly grafting glycidyl methacrylate monomer to cellulose. The grafted product was then functionalised by the addition of imidazole. The novel material was then assessed for its ability to adsorb the heavy metals $\mathrm{Cu}$ (II), $\mathrm{Ni}$ (II) and $\mathrm{Pb}$ (II). Uptake levels on the cellulose-g-GMA-imidazole material were $68 \mathrm{mg} \mathrm{g}^{-1} \mathrm{Cu}$ (II), $45 \mathrm{mg} \mathrm{g}^{-1} \mathrm{Ni}(\mathrm{II}), 71 \mathrm{mg} \mathrm{g}^{-1} \mathrm{~Pb}$ (II). These uptake levels compared favourably with those achieved using other naturally occurring materials. The level of uptake of each metal on the modified cellulose material was found, in all cases, to be significantly influenced by aqueous $\mathrm{pH}$. The optimum $\mathrm{pH}$ range in all cases ranged from approximately $\mathrm{pH} 4$ to $\mathrm{pH}$ 5.5. The speed of uptake of each metal on the sorbent material ranged from approximately 40 minutes in the case of $\mathrm{Cu}$ (II) and $\mathrm{Pb}(\mathrm{II})$ to almost 400 minutes for $\mathrm{Ni}$ (II) depending on initial metal concentration in solution. The overall kinetics in each case is best described by the pseudo-second order approach. Almost complete recovery of each metal from the modified cellulose material was possible using a $0.1 \mathrm{M}$ acid solution; however, re-use of the sorbent materials in further adsorption cycles yielded variable outcomes.
\end{abstract}

Keywords: wastewater, heavy metals, adsorption, modified cellulose. 


\section{Introduction}

Heavy metals such as copper, nickel and lead are discharged in wastewaters from a variety of industrial sources including acid mine drainage [1], metallurgical industries [2], electronic industries [3] and electroplating [4]. Many of the heavy metals are needed by plants in trace concentrations but higher concentrations can produce significant toxic effects [5-7].

A variety of technologies are currently employed in the removal of heavy metals from waste streams including chemical precipitation [8], membrane technology [9], ion-exchange [8] and adsorption [10]. Adsorption is one of the more popular treatment processes offering flexibility in design and operation and in many cases produces treated effluents suitable for re-use. Adsorption also is potentially reversible so offers the possibility of regeneration of the adsorbent and its re-use.

Currently there is an increasing research emphasis on the use of naturally occurring materials as adsorbents or supports for adsorbents in the removal of heavy metal from wastewaters. Examples of these polysaccharide-based materials include chitosan [11] and cross-linked chitosan [12] in the removal of $\mathrm{Cu}$ (II) and cross-linked starch gel [13] for the removal of $\mathrm{Pb}$ (II) from wastewaters. Crini [14], in an extensive review of the use of polysaccharidebased materials as adsorbents in wastewaters, has outlined high removal capabilities for certain metal ions as compared to other low cost sorbents and commercial activated carbons. Aswell as excellent sorption capacities, the specificity is mainly influenced by factors such as chemical structure and composition of the polysaccharide based material and by the accessibility of chelating or complexing groups.

Our research work to date $[15,16]$ has focused on the modification of cellulose in a two step reaction. Initially the cellulose is grafted with the monomer glycidyl methacrylate and subsequently it is functionalised with the addition of imidazole. Figure 1 outlines the overall structure of the sorbent

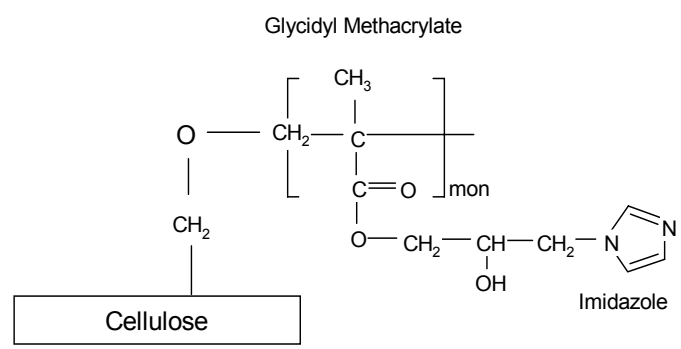

Figure 1: Cellulose-g-GMA-imidazole structure.

material. The presence of the imidazole provides binding sites for the adsorbing heavy metal. Studies have been carried out in which the binding of copper, nickel and lead to this modified cellulose material and this paper seeks to provide 
a comparison of uptake of each metal by the modified cellulose material in comparison to alternative adsorbents.

\section{Methodology}

\subsection{Preparation of Cellulose-g-GMA-imidazole}

Cellulose $(0.5 \mathrm{~g})$ was placed in a glass grafting apparatus along with $30 \mathrm{~mL}$ of deionized water at $30^{\circ} \mathrm{C}$ under a nitrogen atmosphere. Cerium Ammonium Nitrate $(0.05 \mathrm{M})$ and $10 \mathrm{~mL}$ of $0.1 \mathrm{M}$ nitric acid were added and allowed to react with the cellulose for $15 \mathrm{~min}$. Glycidyl methacrylate monomer $(0.35 M)$ was then added and left to react for a further 2 hours. On completion of the reaction, the Cell-g-GMA product was removed and soxhlet extracted with acetone for $12 \mathrm{~h}$ to remove any GMA homopolymer. The Cell-g-GMA was then dried at $60^{\circ} \mathrm{C}$ and imidazole $(3.0 \mathrm{~g})$ was reacted with the cellulose- $g$-GMA fibres $(3.0 \mathrm{~g})$ in $120 \mathrm{~mL}$ dimethyl formamide solution at $70^{\circ} \mathrm{C}$. The cellulose-g- GMA-imidazole material was then filtered, rinsed with water, soxhlet extracted with methanol for 6 hours and dried in a vacuum oven at $70^{\circ} \mathrm{C}$ under vacuum.

\subsection{Adsorption isotherms}

A range of $\mathrm{Cu}(\mathrm{II}), \mathrm{Pb}(\mathrm{II})$ and $\mathrm{Ni}(\mathrm{II})\left(20-2000 \mathrm{mg} \mathrm{dm}^{-3}\right.$ ) adsorption solutions were prepared separately by dissolving appropriate amounts of copper(II)sulphate, $\quad \mathrm{Cu}\left(\mathrm{SO}_{4}\right) .5 \mathrm{H}_{2} \mathrm{O}, \quad$ lead(II)nitrate, $\quad \mathrm{Pb}\left(\mathrm{NO}_{3}\right)_{2} \quad$ or nickel(II)sulphate, $\mathrm{NiSO}_{4} \cdot 6 \mathrm{H}_{2} \mathrm{O}$ (Merck, Germany) in deionised water. From each flask, a $25 \mathrm{ml}$ aliquot was removed and placed in a separate $50 \mathrm{ml}$ plastic vial and $0.2 \mathrm{~g}$ of the adsorbent cellulose-g-GMA-imidazole was added to each vial. All vials were then sealed and placed in a temperature controlled water bath at $23^{\circ} \mathrm{C}$ for either $120 \mathrm{mins}$ for $\mathrm{Cu}(\mathrm{II})$ and $\mathrm{Pb}$ (II) or $400 \mathrm{mins}$ for $\mathrm{Ni}(\mathrm{II})$. The vials were subsequently centrifuged at $4,000 \mathrm{rpm}$ for 15 minutes. $10 \mathrm{~cm}^{3}$ of each supernatant was then removed and suitably diluted with de-ionised water and analysed by atomic absorption spectrophotometry (AAS) (Varian SpectraAA 220). Blank solutions containing equivalent initial concentrations of either $\mathrm{Cu}$ (II), $\mathrm{Pb}$ (II) or $\mathrm{Ni}$ (II) but without addition of the adsorbent (cellulose-g-GMAimidazole) were prepared and put through the identical procedures. Standard AAS solutions were prepared in the range $1-20 \mathrm{mg} \mathrm{dm}^{-3}$ for $\mathrm{Cu}(\mathrm{II}), \mathrm{Pb}(\mathrm{II})$ and $\mathrm{Ni}$ (II) using $1000 \mathrm{mg} \mathrm{dm}^{-3}$ AAS stock solutions (Reagecon Diagnostics, Ireland). Samples and blanks were run in triplicate to ensure reproducibility and accuracy.

\section{$2.3 \mathrm{pH}$ studies}

The effect of initial solution $\mathrm{pH}$ on $\mathrm{Cu}(\mathrm{II}), \mathrm{Pb}(\mathrm{II})$ and $\mathrm{Ni}(\mathrm{II})$ adsorption onto cellulose-g-GMA-imidazole was studied at $23{ }^{\circ} \mathrm{C}$. A $1000 \mathrm{mg} \mathrm{dm}^{-3}$ stock solution was prepared by dissolving appropriate amounts of the sulphate salt of each metal in deionised water. A $25 \mathrm{~cm}^{3}$ aliquot of this stock solution was removed and placed in each of six $50 \mathrm{~cm}^{3}$ plastic vials and $0.2 \mathrm{~g}$ of the adsorbent (cellulose-g-GMA-imidazole) was added. The $\mathrm{pH}$ of the solution in each vial 
was adjusted to yield $\mathrm{pH}$ values ranging from $\mathrm{pH} 2$ to 7 . Adsorption was then allowed to proceed for $60 \mathrm{~min}$ in the case of $\mathrm{Cu}$ (II) and $\mathrm{Pb}$ (II) and $400 \mathrm{~min}$ for $\mathrm{Ni}$ (II) and the metal adsorption level was measured for each of the six vials in an analogous way to that outlined in the adsorption isotherms methodology.

\subsection{Kinetics studies}

Adsorption kinetics for $\mathrm{Cu}(\mathrm{II}), \mathrm{Pb}$ (II) and $\mathrm{Ni}(\mathrm{II})$ uptake on the cellulose-g-GMAimidazole adsorbent were studied separately using a batch technique at $23^{\circ} \mathrm{C}$. At each of three initial metal ion concentrations of 400, 600 and $800 \mathrm{mg} \mathrm{dm}^{-3}$ for $\mathrm{Pb}(\mathrm{II})$ and 100, 300 and $600 \mathrm{mg} \mathrm{dm}^{-3}$ for both $\mathrm{Ni}(\mathrm{II})$ and $\mathrm{Cu}(\mathrm{II})$, a kinetic experiment was carried out. Known weights of the adsorbent $(0.2 \mathrm{~g})$ were added to each of 10 vials containing $25 \mathrm{ml}$ of the initial concentration metal ion solution. Each vial was shaken in a temperature controlled water bath for a specific time period ranging from 10 minutes to 120 minutes contact time for $\mathrm{Cu}$ (II) and $\mathrm{Pb}$ (II) and up to 400 minutes in the case of the $\mathrm{Ni}$ (II) experiments and subsequently centrifuged. The concentration of each metal ion before and after adsorption was determined by AAS. The amount of each metal adsorbed was calculated from its initial and final concentrations in the aqueous phase.

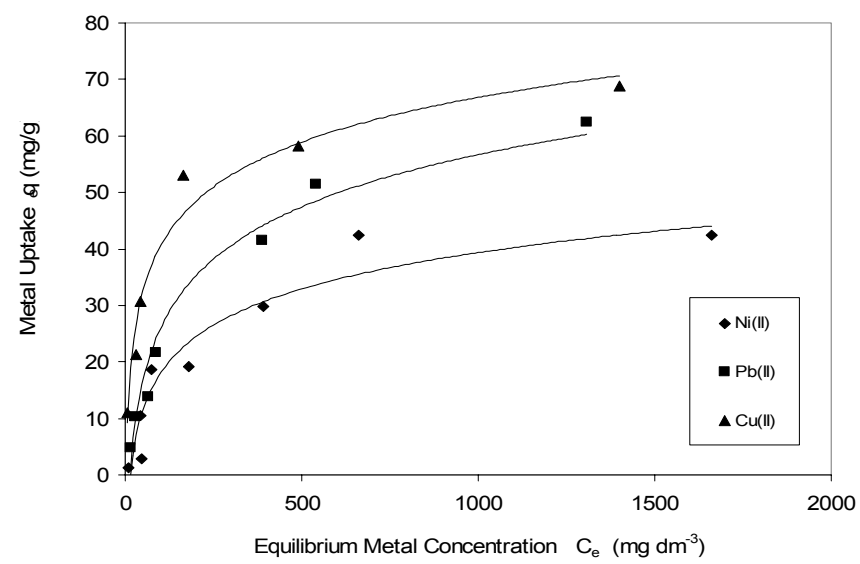

Figure 2: Adsorption isotherm plots for metal uptakes on Cellulose-g-GMAimidazole.

\section{Results and discussion}

\subsection{Adsorption}

The adsorption isotherms for uptake of $\mathrm{Cu}(\mathrm{II}), \mathrm{Pb}$ (II) and $\mathrm{Ni}(\mathrm{II})$ on the celluloseg-GMA-imidazole material, at $23^{\circ} \mathrm{C}$, are shown in figure 2 . The uptake of $\mathrm{Cu}(\mathrm{II})$, $\mathrm{Pb}(\mathrm{II})$ and $\mathrm{Ni}(\mathrm{II})$ reached levels of $68.5,71.9$ and $45.2 \mathrm{mg} \mathrm{g}^{-1}$ respectively. Using equation (1) the Langmuir [17] adsorption approach was applied to the isotherm data: 


$$
q_{e}=\frac{K_{L} \cdot C_{e}}{1+A_{L} C_{e}}
$$

Where $\mathrm{q}_{\mathrm{e}}$ is the amount of metal ion adsorbed in $\mathrm{mg} \mathrm{g}^{-1}, \mathrm{C}_{\mathrm{e}}$ is equilibrium concentration of metal ion in solution in $\mathrm{mg} \mathrm{dm}^{-3}, \mathrm{~K}_{\mathrm{L}}$ and $\mathrm{A}_{\mathrm{L}}$ are Langmuir constants. A plot of $\mathrm{C}_{\mathrm{e}} / \mathrm{q}_{\mathrm{e}}$ versus $\mathrm{C}_{\mathrm{e}}$ from the linear form of eqn (1) was used to determine the values of $\mathrm{K}_{\mathrm{L}}$ (intercept) and $\mathrm{A}_{\mathrm{L}} / \mathrm{K}_{\mathrm{L}}$ (slope). Saturation coverage on the adsorbent was obtained as $\mathrm{K}_{\mathrm{L}} / \mathrm{A}_{\mathrm{L}}$. Application of the Langmuir model to the adsorption isotherm data resulted in a strong correlation between the Langmuir approach and the uptake of each metal ion. The calculated parameters for the Langmuir constants for each adsorption process are presented in table $1 . \mathrm{K}_{\mathrm{L}} / \mathrm{A}_{\mathrm{L}}$ was used to estimate the saturation coverage for $\mathrm{Cu}(\mathrm{II}), \mathrm{Pb}(\mathrm{II})$ and $\mathrm{Ni}(\mathrm{II})$ on the adsorbent.

Table 1: $\quad$ Langmuir Constants for $\mathrm{Cu}(\mathrm{II}), \mathrm{Pb}(\mathrm{II})$ and $\mathrm{Ni}(\mathrm{II})$ adsorption on Cellulose-g-GMA-imidazole.

\begin{tabular}{cccccc}
\hline \multicolumn{6}{c}{ Langmuir Isotherm Data } \\
\hline Metal Ion & $\begin{array}{c}\text { Temperature } \\
\left({ }^{\circ} \mathrm{C}\right)\end{array}$ & $\begin{array}{c}\mathrm{K}_{\mathrm{L}} \\
\left(\mathrm{dm}^{3} \mathrm{~g}^{-1}\right)\end{array}$ & $\begin{array}{c}\mathrm{A}_{\mathrm{L}} \\
\left(\mathrm{dm}^{3} \mathrm{mg}^{-1}\right)\end{array}$ & $\begin{array}{c}\mathrm{K}_{\mathrm{L}} / \mathrm{A}_{\mathrm{L}} \\
\left(\mathrm{mg} \mathrm{g}^{-1}\right)\end{array}$ & $\mathrm{R}^{2}$ \\
\hline $\mathrm{Cu}(\mathrm{II})$ & 23 & 1.55 & 0.023 & 68.5 & 0.995 \\
$\mathrm{~Pb}(\mathrm{II})$ & 23 & 0.33 & 0.005 & 71.9 & 0.991 \\
$\mathrm{Ni}(\mathrm{II})$ & 23 & 0.17 & 0.003 & 45.2 & 0.980 \\
\hline
\end{tabular}

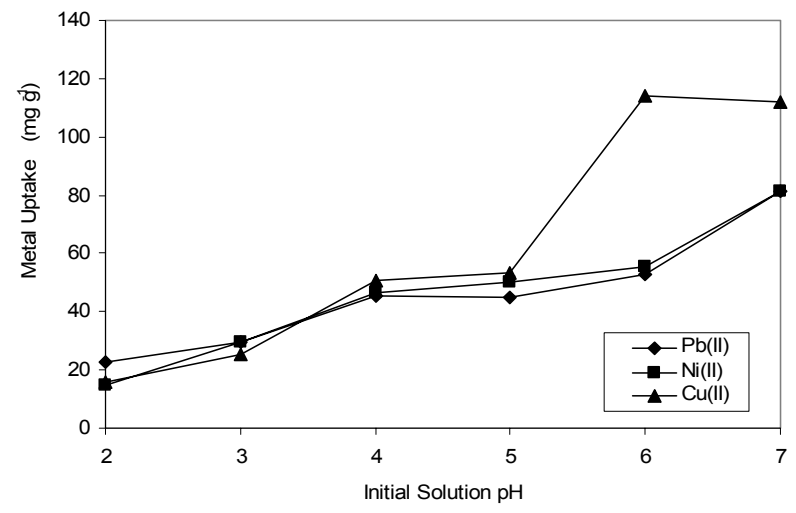

Figure 3: Influence of solution $\mathrm{pH}$ on metal uptake.

\subsection{Influence of $\mathrm{pH}$}

The effect of initial solution $\mathrm{pH}$ on the sorption of each metal onto cellulose- $g$ GMA-imidazole was studied at room temperature by varying the $\mathrm{pH}$ between 2.0 and 7.0 (Fig. 3). The plot can be divided into three $\mathrm{pH}$ regions. In the first region, from $\mathrm{pH} 2$ to 4, competition for adsorption sites on the cellulose-g-GMAimidazole between protons $\left(\mathrm{H}^{+}\right)$and the metal ions exists. Uptake of the metal 
ions ranges between $25-40 \%$ of the expected maximum adsorption level. In the second region of $\mathrm{pH} 4.0-6.0$, the influence of $\mathrm{H}^{+}$is minimised and maximal $\mathrm{Pb}(\mathrm{II})$ and $\mathrm{Ni}(\mathrm{II})$ uptake occurs. This maximal range is narrower for $\mathrm{Cu}(\mathrm{II})$ uptake $(\mathrm{pH} 4-\mathrm{pH} 5)$. In this central region of each plot the level of uptake corresponds with uptake levels based on each isotherm plot. The final region of the plot extends from $\mathrm{pH} 5.5$ to $\mathrm{pH} 7$ where a sharp apparent increase in uptake is observed. This sharp increase is largely due to precipitation of $\mathrm{Cu}(\mathrm{II}), \mathrm{Pb}$ (II) and $\mathrm{Ni}$ (II) as their respective hydroxide species and is not as a result of an adsorption process.

\subsection{Kinetics of uptake}

The influence of initial metal concentration on the rate of $\mathrm{Cu}$ (II), $\mathrm{Pb}$ (II) and $\mathrm{Ni}$ (II) uptake was assessed. In the case of $\mathrm{Cu}$ (II) and $\mathrm{Pb}$ (II) equilibrium adsorption was achieved within 40 minutes of contact. Ni(II) uptake proved considerably slower and required a contact time of approximately 400 minutes. Pseudo-second order kinetics (eqn. 2) can be used to assess the dependency of each process on the sorbed $\mathrm{Cu}(\mathrm{II}), \mathrm{Pb}(\mathrm{II})$ or $\mathrm{Ni}(\mathrm{II})$ concentrations.

$$
\frac{t}{q_{t}}=\frac{1}{k_{2} q_{e}^{2}}+\frac{1}{q e} t
$$

where $\mathrm{k}_{2}$ is the overall rate constant for the adsorption process [ $\mathrm{dm}^{3}\left(\mathrm{mg} \mathrm{min}^{-1}\right)$, $\mathrm{q}_{\mathrm{e}}$ is the amount of metal ion adsorbed at equilibrium ( $\mathrm{mg} \mathrm{g}^{-1}$ ) and $\mathrm{q}_{\mathrm{t}}$ is the amount of metal ion adsorbed at any time $\mathrm{t}\left(\mathrm{mg} \mathrm{g}^{-1}\right)$. The initial sorption rate, $h$, as $\mathrm{t} \rightarrow 0$ can be defined as

$$
h=k_{2} q_{e}^{2} \text {. }
$$

The overall results and constants for the pseudo-second order approach are presented in table 2 .

High correlation co-efficients $\left(R^{2}\right)$ in all cases were observed indicating overall compliance with the pseudo-second order approach. The data also shows that the initial sorption rates ( $h$ values) decreased with an increase in initial $\mathrm{Pb}(\mathrm{II})$ concentration and increased with an increase in initial $\mathrm{Cu}(\mathrm{II}), \mathrm{Ni}$ (II) concentrations.

\subsection{Regeneration of cellulose-g-GMA-imidazole}

Table 3 outlines the extent of recovery of adsorbed metal versus $\mathrm{pH}$ of regenerant solution. Varying results were obtained when the metal loaded cellulose-g-GMA-imidazole sorbent was regenerated. Using acid solutions of $\mathrm{pH}$ 1 , almost complete recovery of each of the metal was achievable. Increasing the $\mathrm{pH}$ of the regenerating solution to $\mathrm{pH} 2$ led to a considerable drop in metal recovery levels to approximately $30 \%$ of the adsorbed metal. As the $\mathrm{pH}$ was raised further towards neutrality the extent of metal recovery continued to decline further. While $100 \%$ recovery of the metals was feasible at $\mathrm{pH} 1$, it was also found that the adsorbent material, after metal recovery, showed only limited capacity to re-adsorb the metals in a second cycle of the process. 
Table 2: $\quad$ Effect of initial $\mathrm{Cu}(\mathrm{II}), \mathrm{Pb}(\mathrm{II})$ and $\mathrm{Ni}(\mathrm{II})$ concentrations on sorption data on Cellulose-g-GMA-imidazole using the pseudo-second order approach at $23^{\circ} \mathrm{C}$.

\begin{tabular}{|c|c|c|c|c|}
\hline \multicolumn{5}{|c|}{ Pseudo-second order kinetic parameters - Cu(II) } \\
\hline Initial & Correlation & $\mathrm{Cu}(\mathrm{II})$ & Rate & Initial \\
\hline $\begin{array}{c}\text { Conc. } \\
\mathrm{Cu}(\mathrm{II}) \\
\left(\mathrm{mg} \mathrm{dm}^{-3}\right)\end{array}$ & $\begin{array}{c}\text { Co-efficient } \\
\mathrm{R}^{2}\end{array}$ & $\begin{array}{l}\text { uptake } \\
\left(\mathrm{mg} \mathrm{g}^{-1}\right)\end{array}$ & $\begin{array}{r}\text { Constant, } \mathrm{k}_{2} \\
\left(\mathrm{~g} \mathrm{mg}^{-1} \mathrm{~min}^{-1}\right)\end{array}$ & $\begin{array}{c}\text { sorption } \\
\text { Rate, } \mathrm{h} \\
\left(\mathrm{mg} \mathrm{g}^{-1} \mathrm{~min}^{-1}\right)\end{array}$ \\
\hline 100 & 0.999 & 11.7 & $3.59 \times 10^{-2}$ & 4.9 \\
\hline 300 & 0.999 & 33.1 & $1.36 \times 10^{-2}$ & 15.0 \\
\hline 600 & 0.999 & 55.6 & $6.54 \times 10^{-3}$ & 20.2 \\
\hline \multicolumn{5}{|c|}{ Pseudo-second order kinetic parameters - Pb(II) } \\
\hline Initial & Correlation & $\mathrm{Pb}(\mathrm{II})$ & Rate & Initial \\
\hline $\begin{array}{c}\text { Conc. } \\
\mathrm{Pb}(\mathrm{II}) \\
\left(\mathrm{mg} \mathrm{dm}^{-3}\right)\end{array}$ & $\begin{array}{c}\text { Co-efficient } \\
\mathrm{R}^{2}\end{array}$ & $\begin{array}{l}\text { uptake } \\
\left(\mathrm{mg} \mathrm{g}^{-1}\right)\end{array}$ & $\begin{array}{r}\text { Constant, } \mathrm{k}_{2} \\
\left(\mathrm{~g} \mathrm{mg}^{-1} \mathrm{~min}^{-1}\right)\end{array}$ & $\begin{array}{c}\text { sorption } \\
\text { Rate, } \mathrm{h} \\
\left(\mathrm{mg} \mathrm{g}^{-1} \mathrm{~min}^{-1}\right)\end{array}$ \\
\hline 400 & 0.999 & 36.1 & $2.75 \times 10^{-2}$ & 35.9 \\
\hline 600 & 0.998 & 43.8 & $9.95 \times 10^{-3}$ & 19.1 \\
\hline 800 & 0.998 & 46.9 & $8.82 \times 10^{-3}$ & 19.4 \\
\hline \multicolumn{5}{|c|}{ Pseudo-second order kinetic parameters - Ni(II) } \\
\hline Initial & Correlation & $\mathrm{Ni}(\mathrm{II})$ & Rate & Initial \\
\hline $\begin{array}{c}\text { Conc. } \\
\mathrm{Ni}(\mathrm{II}) \\
\left(\mathrm{mg} \mathrm{dm}^{-3}\right)\end{array}$ & $\begin{array}{c}\text { Co-efficient } \\
\mathrm{R}^{2}\end{array}$ & $\begin{array}{l}\text { uptake } \\
\left(\mathrm{mg} \mathrm{g}^{-1}\right)\end{array}$ & $\begin{array}{r}\text { Constant, } \mathrm{k}_{2} \\
\left(\mathrm{~g} \mathrm{mg}^{-1} \mathrm{~min}^{-1}\right)\end{array}$ & $\begin{array}{c}\text { sorption } \\
\text { Rate, } \mathrm{h} \\
\left(\mathrm{mg} \mathrm{g}^{-1} \mathrm{~min}^{-1}\right)\end{array}$ \\
\hline 100 & 0.983 & 4.7 & $1.38 \times 10^{-2}$ & 0.1754 \\
\hline 300 & 0.982 & 13.38 & $2.78 \times 10^{-3}$ & 0.4993 \\
\hline 600 & 0.983 & 21.17 & $1.71 \times 10^{-3}$ & 0.7692 \\
\hline
\end{tabular}

Table 3: Recovery of adsorbed metals from Cellulose-g-GMA-imidazole.

\begin{tabular}{lcccccc}
\hline \multicolumn{7}{c}{ \% Metal Recovery } \\
\hline $\mathbf{p H}$ & $\mathbf{1}$ & $\mathbf{2}$ & $\mathbf{3}$ & $\mathbf{4}$ & $\mathbf{5}$ & $\mathbf{6}$ \\
\hline $\mathrm{Cu}(\mathrm{II})$ & 96 & 28 & 12 & 10 & 9 & 9 \\
$\mathrm{~Pb}(\mathrm{II})$ & 99 & 36 & 19 & 22 & 6 & 6 \\
$\mathrm{Ni}(\mathrm{II})$ & 100 & 34 & 16 & 14 & 13 & 14 \\
\hline
\end{tabular}

\subsection{Comparison of $\mathrm{Cu}(\mathrm{II}), \mathrm{Pb}(\mathrm{II})$ and $\mathrm{Ni}(\mathrm{II})$ on alternative adsorbents}

The $\mathrm{Cu}(\mathrm{II}), \mathrm{Pb}(\mathrm{II})$ and $\mathrm{Ni}(\mathrm{II})$ uptake levels on the cellulose-g-GMA-imidazole material were compared with the results of other research studies as outlined in table 4.

The sorbent material (cellulose-g-GMA-imidazole) used in our own research shows a relatively strong $\mathrm{Cu}(\mathrm{II}), \mathrm{Pb}(\mathrm{II})$ and $\mathrm{Ni}(\mathrm{II})$ adsorption capacities of 68.5 , 71.9 and $45.2 \mathrm{mg} \mathrm{g}^{-1}$ respectively. In the case of $\mathrm{Cu}$ (II) uptake, sawdust modified with acrylic acid yielded highest adsorption values with chabazite, a zeolite 
Table 4: $\quad$ Comparison of adsorption levels for $\mathrm{Cu}(\mathrm{II}), \mathrm{Pb}$ (II) and $\mathrm{Ni}$ (II) on a range of natural/modified sorbent materials.

\begin{tabular}{lllll}
\hline Adsorbent & $\mathrm{Cu}(\mathrm{II})$ & $\mathrm{Pb}(\mathrm{II})$ & $\mathrm{Ni}(\mathrm{II})$ & Ref. \\
\hline Cellulose/cysteine & 22 & 28 & 8 & {$[18]$} \\
Sawdust/Acrylic acid & 104 & & 97 & {$[19]$} \\
Cellulose-GMA-Imidazole & 68.5 & 71.9 & 45.2 & $\begin{array}{l}\text { This } \\
\text { research }\end{array}$ \\
& & & & {$[20][21]$} \\
Clinoptilolite & 25.4 & 124 & 0.9 & {$[22]$} \\
Chabazite & 5.1 & 6.0 & 4.5 & {$[23]$} \\
Chitosan & 16.8 & 16.4 & 2.4 & {$[11]$} \\
Crosslinked chitosan & 62.5 & & & {$[13]$} \\
Cross-linked starch gel & & 433 & & \\
\hline
\end{tabular}

material, showing limited adsorption capacity. Cross-linked chitosan also shows strong $\mathrm{Cu}$ (II) uptake. Cross-linked starch gel showed extremely high uptake of $\mathrm{Pb}$ (II) with chabazite showing weak uptake of $\mathrm{Pb}$ (II). Our material can best be described as mid-range in terms of $\mathrm{Pb}$ (II) uptake relative to the other adsorbents. Many of the adsorbents show limited Ni(II) uptake with the cellulose-g-GMAimidazole material from this work showing strong Ni(II) uptake.

\section{Conclusions}

The prepared adsorbent, cellulose-g-GMA-imidazole, proved to be an efficient adsorbent for the removal of $\mathrm{Cu}$ (II), $\mathrm{Pb}$ (II) and $\mathrm{Ni}$ (II) from aqueous solution. The adsorption isotherms indicated clearly that the reaction product has an adsorptive capacity of approximately $69 \mathrm{mg} \mathrm{g}^{-1}, 72 \mathrm{mg} \mathrm{g}^{-1}$ and $45 \mathrm{mg} \mathrm{g}^{-1}$ for $\mathrm{Cu}(\mathrm{II}), \mathrm{Pb}(\mathrm{II}), \mathrm{Ni}$ (II) respectively, at a temperature of $23^{\circ} \mathrm{C}$. The Langmuir model best described each of the metal adsorption processes. The speed of adsorption for $\mathrm{Cu}(\mathrm{II})$ and $\mathrm{Pb}$ (II) was rapid (40min) with uptake of $\mathrm{Ni}$ (II) being considerably slower (400min). The overall adsorption levels of $\mathrm{Cu}$ (II), $\mathrm{Pb}$ (II) and $\mathrm{Ni}$ (II) on the cellulose-g-GMA-imidazole compared very favourably with uptake levels outlined in a range of research studies using other unmodified and modified naturally occurring materials.

\section{References}

[1] Aswathanarayana, U., Mineral Resources Management and the Environment. Routledge, Netherlands, pp. 223-256, 2003.

[2] Rule, K.L., Comber, S.D.W., Ross, D., Thornton, A., Makropoulos, C.K. \& Rautiu, R., Diffuse sources of heavy metals entering an urban wastewater catchment. Chemosphere, 63(1), pp. 64-72, 2006.

[3] Veglio, F., Quaresima, R., Fornari, P. \& Ubaldini, S., Recovery of valuable metals from electronic and galvanic industrial wastes by leaching and electrowinning. Waste Management, 23(3), pp. 245-252, 2003. 
[4] Castelblanque, J. \& Salimbeni, F., NF and RO membranes for the recovery and reuse of water and concentrated metallic salts from waste water produced in the electroplating process. Desalination, 167, pp. 65-73, 2004.

[5] Pagliuca, A. \& Mufti, G.J., Lead Poisoning: an age-old problem. British Medical Journal, 300, pp. 830, 1990.

[6] Theophanides, T. \& Anastassopoulou, J., Copper and Carcinogenesis, Critical Reviews, Oncology/Haematology, 42(1), pp. 57-64, 2002.

[7] Nordberg, G., Fowler, B., Nordberg, M.\& Friberg, L.F., Handbook on the Toxicity of Metals, third ed., Elsevier, Amsterdam, pp. 743-758, 2007.

[8] Aderhold, D., Williams, C.J. \& Edyvean, R.G.J., The removal of heavymetal ions by seaweeds and their derivatives. Bioresource Technology, 58(1), pp. 1-6, 1996.

[9] Madaeni, S.S. \& Mansourpanah, Y., COD Removal from Concentrated Wastewater Using Membranes. Filtration \& Separation, 40(6), pp. 40-46, 2003.

[10] Wang, Y.H., Lin, S.H. \& Juang R.S., Removal of heavy metal ions from aqueous solutions using various low-cost adsorbents. Journal of Hazardous Materials, 102(2-3), pp. 291-302, 2003.

[11] Wan Ngah, W.S., Endud, C.S. \& Mayanar, R., Removal of copper(II) ions from aqueous solution onto chitosan and cross-linked chitosan beads. React Funct Polym., 50, pp. 181-90, 2002

[12] Cao, Z., Ge, H. \& Lai, S., Studies on synthesis and adsorption properties of chitosan cross-linked by glutaraldehyde and $\mathrm{Cu}(\mathrm{II})$ as template under microwave irradiation. Eur Polym J, 37, pp. 2141-2143, 2001.

[13] Zhang, L.M. \& Chen, D.Q., An investigation of adsorption of lead(II) and copper(II) ions by water-insoluble starch graft copolymers. Colloids Surf A Phys Eng Aspects, 205, pp. 231-236, 2002.

[14] Crini, G., Recent developments in polysaccharide-based materials used as adsorbents in wastewater treatment. Progress in Polymer Science, 30(1), pp. 38-70, 2005.

[15] O'Connell, D.W., Birkinshaw, C. \& O'Dwyer T.F., A chelating cellulose adsorbent for the removal of $\mathrm{Cu}(\mathrm{II})$ from aqueous solutions. Journal of Applied Polymer Science, 99, pp. 2888-2897, 2006.

[16] O'Connell, D.W., Birkinshaw, C. \& O'Dwyer T.F., Water Pollution VIII: Modelling, Monitoring and Management., Eds. Brebbia C.A. and Antunes do Carmo J.S., WIT Press, Southampton, U.K., Section 9, Wastewater Treatment, pp. 489-498, 2006.

[17] Langmuir, I., The adsorption of gases on plane surfaces of glass, mica and platinum. J Am. Chem. Soc., 40, pp. 1361, 1918.

[18] Aoki, N., Fukushima, K., Kurakata, H., Sakamoto, M. \& Furuhata, K., 6Deoxy-6-mercaptocellulose and its S-substituted derivatives as sorbents for metal ions. Reactive and Functional Polymers, 42(3), pp. 223-233, 1999.

[19] Gaey, M., Marchetti,V., Clement, A., Loubinoux, B. \& Gerardin, P., Decontamination of synthetic solutions containing heavy metals using chemically modified sawdusts bearing polyacrylic acid chains. Journal of Wood Science, 46, pp. 331-333, 2000. 
[20] Peric, J., Trgo, M. \& Vukojevic Medvidovic, N., Removal of zinc, copper and lead by natural zeolite: A comparison of adsorption isotherms. Water Research, 38(7), pp. 1893-1899, 2004.

[21] Berber-Mendoza, M.S., Leyva-Ramos, R., Alonso-Davila, P., MendozaBarron, J. \& Diaz-Flores, P.E., Effect of $\mathrm{pH}$ and temperature on the ionexchange isotherm of $\mathrm{Cd}(\mathrm{II})$ and $\mathrm{Pb}(\mathrm{II})$ on clinoptilolite. Journal of Chemical Technology and Biotechnology, 301, pp. 40-45, 2006.

[22] Ouki, S.K. \& Kavannagh, M., Performance of natural zeolites for the treatment of mixed metal contaminated effluents. Waste Management \& Research, 15(4), pp. 383-394, 1997.

[23] Huang, C.P., Chung, Y.C. \& Liou, M.R., Adsorption of Cu(II) and Ni(II) by pelletized biopolymer, J. Hazard. Mater., 45, pp. 265-277, 1996. 